\title{
PENILAIAN TINGKAT KESEHATAN KOPERASI SYARIAH BERDASARKAN PERATURAN KEMENTERIAN KOPERASI DAN UKM
}

\author{
Prayogo P. Harto ${ }^{1}$, Umi Amaliah ${ }^{2}$, Sri Mulyati ${ }^{3}$
}

\author{
${ }^{1}$ Program Studi Akuntansi Syariah, Sekolah Tinggi Ekonomi Islam SEBI, Depok, Jawa Barat. \\ Email:prayogo.p.harto@gmail.com \\ ${ }^{2}$ Staf Rumah Zakat. Email: umiamaliah10@gmail.com, \\ ${ }^{3}$ Program Studi Akuntansi Syariah, Sekolah Tinggi Ekonomi Islam SEBI, Depok, Jawa Barat. \\ Email:mulyatie.dd@gmail.com,
}

\begin{abstract}
This study aims to determine the level of health of Sharia Multipurpose Cooperative $X$ in Depok City based on the standards of The Cooperative Minister Regulation Number: 07/Per/Dep. 6/ IV/2016 concerning Health Assessment Guidelines for Sharia Cooperative. Assessment health level of cooperatives based on 8 aspects: aspects of capital, quality, management, efficiency, liquidity, independence and growth, cooperative identity, and promises to sharia principles. The results showed that the health level of Syariah Cooperative X in 2017 obtained a score of 61.99 categorized in Supervision.
\end{abstract}

Keywords: Sharia Cooperative, Financial Performance, Healt Assessment, Govement Regulation

\section{PENDAHULUAN}

Perkembangan koperasi di Indonesia, dari tahun ke tahun, menunjukkan pertumbuhan positif. Data Kementerian Koperasi menyebutkan, jika pada tahun 2013, Indonesia memiliki 143.117 unit koperasi aktif. Jumlah tersebut meningkat menjadi 147.249 unit koperasi aktif pada tahun 2014. Angka itu naik lagi menjadi 150.223 unit koperasi aktif pada tahun 2015. Dari jumlah koperasi aktif tersebut, sebanyak $1,5 \%$ atau 2.253 unit adalah koperasi simpan pinjam dan pembiayaan syariah (Kementerian Koperasi, 2016).

Namun, meski dari tahun ke tahun jumlah koperasi di Indonesia mengalami pertumbuhan, sejumlah masalah masih mengikutinya. Penelitian Hendriani, Ningsih, dan Fitri (2015) menyimpulkan masalah-masalah yang dihadapi koperasi, antara lain, manajemen pengelolaan koperasi masih lemah, kurang memiliki semangat kewirausahaan, dan badan pengawas koperasi kurang profesional. Hal ini disinyalir berdampak pada rendahanya tingkat kesehatan koperasi. Tinggi rendahnya tingkat kesehatan akan menentukan kelangsungan koperasi, apakah dapat bertahan atau tidak, di masa depan. 


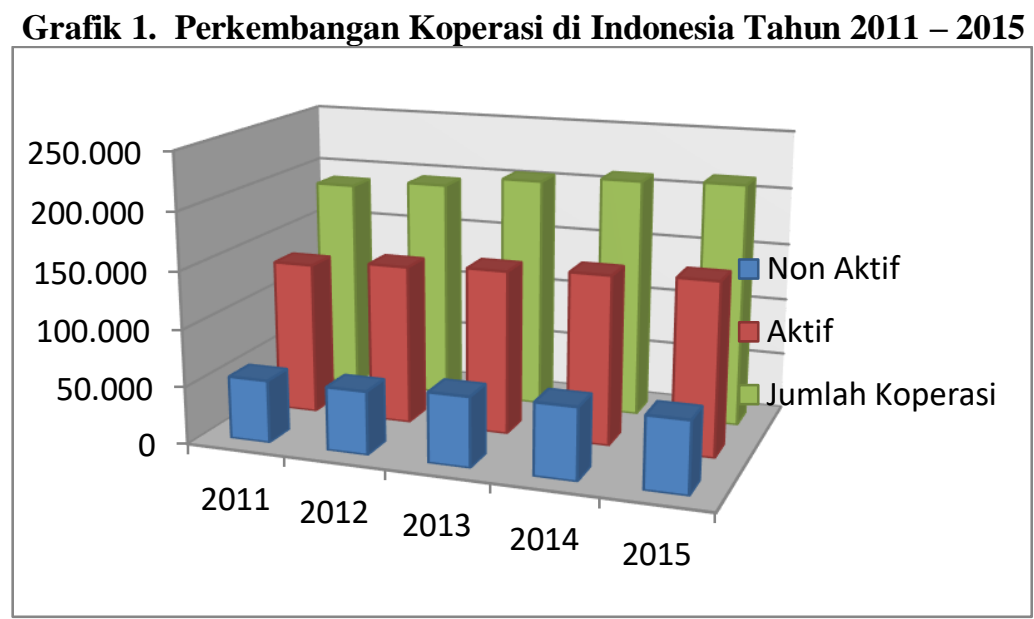

Sumber: Kementerian Koperasi Republik Indonesia (2016)

Penelitian tentang kesehatan koperasi syariah, sebelumnya pernah dilakukan Soedarsa dan Natalia (2016) dan Eindrias dan Azizah (2017) yang masing-masing mengambil objek penelitian koperasi di Kabupaten Tulang Bawang Barat dan Kabupaten Kediri. Metode yang digunakan untuk menilai tingkat kesehatan koperasi yang meliputi 7 aspek yaitu aspek permodalan, aspek kualitas aktiva produktif, aspek manajemen, aspek efisiensi, aspek likuiditas, aspek kemandirian dan pertumbuhan serta aspek jati diri koperasi.

Sementara, penelitian tingkat kesehatan koperasi syariah pernah dilakukan Yusuf (2016) dengan objek Koperasi Jasa Keuangan Syariah BMT Al- Munawwarah. Alat penilaian kesehatan yang digunakan adalah metode Capital, Asset, Management, Earning, Liquidity (CAMEL) yang disesuaikan dengan beberapa tambahan seperti aspek syariah.

Sebenarnya, sejak tahun 2016, Kementerian Koperasi telah mengeluarkan pedoman tentang penilaian kesehatan koperasi syariah yang tertuang dalam Peraturan Deputi Kementerian Koperasi Nomor: 07/ Per/Dep.6/IV/2016 tentang Pedoman Penilaian Kesehatan Koperasi Simpan Pinjam dan Pembiayaan Syariah dan Unit Simpan Pinjam dan Pembiayaan Syariah dengan dasar peraturan pasal 31 ayat 3 Permenkop No. 16/Per/M.KUKM/IX/2015. Namun, sejauh yang peneliti ketahui, masih relatif sedikit penelitian yang secara empiris menggunakan pedoman tersebut untuk menilai tingkat kesehatan suatu koperasi syariah.

Oleh karena itu, penelitian ini akan berfokus pada cara pengukuran tingkat kesehatan koperasi syariah menggunakan metode penilaian kesehatan sesuai Peraturan Deputi Kementerian Koperasi tersebut yang meliputi 8 (delapan) aspek, yaitu: permodalan, kualitas aktiva produktif, manajemen, efisiensi, likuiditas, kemandirian dan pertumbuhan, jati diri koperasi, dan prinsip syariah. 
Jurnal Ekonomi dan Perbankan Syariah

Vol. 7. No.2, Agustus 2018: 5-26, ISSN (cet): 2355-1755 | ISSN (online): 2579-

6437

17

\section{LANDASAN TEORI}

Menurut UU No.17 Tahun 2012, koperasi adalah badan hukum yang didirikan oleh orang perseorangan atau badan hukum koperasi, dengan pemisahan kekayaan para anggotanya sebagai modal untuk menjalankan usaha, yang memenuhi aspirasi dan kebutuhan bersama di bidang ekonomi, sosial, dan budaya sesuai nilai dan prinsip koperasi.

Pengertian koperasi secara umum adalah suatu perkumpulan yang beranggotakan orang-orang atau badan hukum, yang memberikan kebebasan kepada anggota untuk bergabung, dengan bekerja sama secara kekeluargaan, dan menjalankan usaha untuk meningkatkan kesejahteraan, khususnya para anggotanya (Sumarsono, 2003, hlm.1).

Sementara, koperasi syariah dapat didefinisikan sebagai usaha ekonomi yang terorganisir secara mantap, demokratis, otonom partisipatif, dan berwatak sosial yang operasionalnya menggunakan prinsip-prinsip yang mengusung etika moral dengan memperhatikan halal atau haramnya sebuah usaha yang dijalankannya sebagaimana diajarkan dalam agama Islam (Buchori, 2012, hlm.4).

Pengertian koperasi syariah juga tertuang dalam Peraturan Menteri Negara Koperasi dan Usaha Kecil dan Menengah Republik Indonesia Nomor: 11/per/M.KUKM/XII/2017 tentang Pelaksanaan Kegiatan Usaha Simpan Pinjam dan Pembiayaan Syariah oleh Koperasi. Menurut peraturan tersebut, pengertian Koperasi Simpan dan Pembiayaan Syariah (KSPPS) adalah koperasi yang kegiatan usaha simpan, pinjam, dan pembiayaan sesuai prinsip syariah, termasuk mengelola zakat, infak, sedekah, dan wakaf.

Di sisi lain, tingkat kesehatan koperasi merupakan suatu tolak ukur untuk kondisi ataupun keadaan koperasi pada suatu periode tertentu. Penilaian tingkat kesehatan koperasi simpan pinjam dapat dinilai berdasarkan beberapa aspek atau beberapa indikator yang sudah ditentukan (Eindrias \& Azizah, 2017). Sementara, tingkat kesehatan koperasi syariah dapat diartikan sebagai suatu kondisi yang dinyatakan dalam kategori sehat, cukup sehat, kurang sehat, dan tidak sehat (Buchori, 2012, hlm.218).

Salah satu cara untuk menilai tingkat kesehatan koperasi syariah adalah dengan berpedoman pada Peraturan Deputi Menteri Koperasi Nomor: 07/ Per/Dep.6/IV/2016 tentang Pedoman Penilaian Kesehatan Koperasi Simpan Pinjam dan Pembiayaan Syariah dan Unit Simpan Pinjam dan Pembiayaan Syariah (Sugiyarso, 2011, hlm.133).

Adapun untuk predikat tingkat kesehatan suatu koperasi syariah dapat dibagi dalam 4 (empat) golongan, yaitu Sehat, Cukup Sehat, Dalam Pengawasan, dan Dalam Pengawasan Khusus (Kementerian Koperasi, 2016, hlm.21). 
8 | Prayogo. P. Harto, Umi Amaliah, Sri Mulyati : Penilaian Tingkat Kesehatan Koperasi Syariah Berdasarkan Peraturan Kementerian Koperasi dan UKM

\section{Tabel 1. Predikat Tingkat Kesehatan Koperasi}

\begin{tabular}{|c|c|}
\hline Skor & Predikat \\
\hline $80.00 \leq \mathrm{X}<100$ & Sehat \\
$66.00 \leq \mathrm{X}<80.00$ & Cukup Sehat \\
\hline $51.00 \leq \mathrm{X}<66.00$ & Dalam Pengawasan \\
\hline $0<51.00$ & Dalam Pengawasan Khusus \\
\hline
\end{tabular}

Sumber: Peraturan Deputi Menteri Koperasi No. 07/ Per/Dep.6/IV/2016

\section{METODE PENELITIAN}

Objek dalam penelitian ini adalah Koperasi Syariah X yang merupakan Koperasi Serba Usaha di daerah Kotamadya Depok dan telah berdiri sejak tahun 2002. Penelitian ini difokuskan untuk mendeskripsikan cara pengukuran tingkat kesehatan Koperasi Syariah X untuk periode laporan keuangan dari tahun 2017.

Adapun metode penilaian kesehatan yang digunakan berpedoman pada Peraturan Deputi Menteri Koperasi Nomor: 07/Per/Dep.6/IV/2016. Ada delapan (8) variabel operasional yang digunakan dalam menganalisis tingkat kesehatan Koperasi syariah, yaitu: (1) Permodalan; (2) Kualitas Aktiva Produktf; (3) Manajemen; (4) Efisiensi; (5) Likuiditas; (6) Kemandirian dan Pertumbuhan; (7) Jati Diri Koperasi; dan (8) Kepatuhan Prinsip Syariah.

Berikut adalah $\mathrm{X}$ langkah-langkah yang dilakukan untuk mengukur tingkat kesehatan Koperasi Syariah :

a. Mengumpulkan data primer dan data sekunder terkait objek dari tahun 2015 sampai tahun 2017 yang berkaitan dengan delapan variabel penelitian. Data tersebut dapat berupa laporan keuangan koperasi selama 2 tahun, transkip wawancara, beserta dokumen penting lainnya.

b. Data-data tersebut kemudian dihitung dengan menggunakan penilaian Peraturan Deputi Menteri Koperasi No. 07/ Per/Dep.6/IV/2016 tentang Pedoman Penilaian Kesehatan Koperasi Simpan Pinjam dan Pembiayaan Syariah dan Usaha Simpan Pinjam dan Pembiayaan Syariah Koperasi untuk mendapatkan skor masing-masing variabel.

c. Skor masing-masing variabel itu kemudian direkapitulasi untuk mendapatkan total skor keseluruhan dan untuk mendapatkan hasil peringkat tingkat kesehatannya.

\section{PEMBAHASAN}

\subsection{TINGKAT KESEHATAN PERMODALAN}

Aspek pertama penilaian kesehatan Koperasi Syariah adalah permodalan. Penilaian dilakukan dengan menggunakan dua rasio permodalan, yaitu (1) Perbandingan Modal Sendiri dengan Total Aset dan (2) Rasio Kecukupan Modal (Capital Adequacy Ratio/CAR).

\subsubsection{Perbandingan Modal Sendiri Terhadap Total Aset}


Jurnal Ekonomi dan Perbankan Syariah

Vol. 7. No.2, Agustus 2018: 5-26, ISSN (cet): 2355-1755 | ISSN (online): 2579-

6437

\section{9}

Rasio Modal Sendiri terhadap Total Aset dimaksudkan untuk mengukur kemampuan Koperasi Syariah dalam menghimpun modal sendiri dibandingkan dengan aset yang dimiliki.

Untuk penetapan tingkat kesehatan rasio Modal Sendiri Terhadap Total Aset ditetapkan dengan cara berikut:

a. Untuk rasio permodalan lebih kecil atau sama dengan 0 diberikan nilai kredit 0 ;

b. Untuk setiap kenaikan rasio permodalan $1 \%$ mulai dari $0 \%$ nilai kredit ditambah 5 dengan maksimum nilai 100;

c. Nilai kredit dikalikan bobot sebesar 5\% maka diperoleh skor permodalan.

Tabel 4. Penetapan Kriteria Rasio Modal Sendiri Terhadap Total Aset

\begin{tabular}{|c|c|c|c|c|}
\hline $\begin{array}{c}\text { Rasio } \\
(\%)\end{array}$ & $\begin{array}{c}\text { Nilai Kredit } \\
\text { (NK) }\end{array}$ & $\begin{array}{c}\text { Bobot } \\
(\%)\end{array}$ & $\begin{array}{c}\text { Skor } \\
\text { (NK x Bobot) }\end{array}$ & Kriteria \\
\hline 0 & 0 & 5 & 0 & \multirow{5}{*}{$\begin{array}{c}0,00-1,25 \text { tidak sehat } \\
1,26-2,50 \text { kurang sehat } \\
2,51-3,75 \text { cukup sehat } \\
3,76-5,00 \text { sehat }\end{array}$} \\
\hline 5 & 25 & 5 & 1,25 & \\
\hline 10 & 50 & 5 & 2,50 & \\
\hline 15 & 75 & 5 & 3,75 & \\
\hline 20 & 100 & 5 & 5,0 & \\
\hline
\end{tabular}

Tabel 5. Perhitungan Rasio Modal Sendiri Terhadap Total Aset

\begin{tabular}{|c|c|c|c|c|c|c|}
\hline $\begin{array}{c}\text { Total Modal } \\
\text { Sendiri (A) }\end{array}$ & Total Aset (B) & $\begin{array}{c}\text { (A/ B) X } \\
\mathbf{1 0 0 \%}\end{array}$ & $\begin{array}{c}\text { Nilai } \\
\text { kredit }\end{array}$ & $\begin{array}{c}\text { Bobot } \\
\text { \% }\end{array}$ & Skor & Kriteria \\
\hline $413.617 .468,46$ & $5.343 .484 .559,70$ & $7,74 \%$ & 38,7 & $5 \%$ & 1,94 & $\begin{array}{c}\text { Kurang } \\
\text { Sehat }\end{array}$ \\
\hline
\end{tabular}

Dari hasil perhitungan, nilai rasio Modal Sendiri Terhadap Total Aset dari Koperasi Syariah X adalah 7,95\% atau skornya sama dengan 2, yang berarti masuk kategori Kurang Sehat. Koperasi Syariah dianggap sehat apabila nilainya maksimal Modal Sendiri Terhadap Total Aset adalah 20\%, yang diartikan koperasi tersebut telah mampu menumbuhan kepercayaan anggotanya untuk mau menyimpan dana pada koperasi bersangkutan.

\subsubsection{Rasio Kecukupan Modal}

Perhitungan rasio CAR diperoleh dengan cara membandingkan Modal Tertimbang terhadap nilai ATMR dikalikan 100\%. Modal Tertimbang adalah jumlah dari hasil kali setiap komponen modal koperasi syariah yang terdapat pada laporan posisi keuangan dengan bobot pengakuan risiko. Sedangkan Aktiva Tertimbang Menurut Risiko (ATMR) adalah hasil perkalian nilai nominal aktiva yang ada dalam laporan posisi keuangan dengan bobot risiko masing-masing komponen aktiva (Sugiyarso, 2011, hlm.136).

Perhitungan rasio CAR ditetapkan dengan tahapan sebagai berikut:

a. Menghitung nilai modal sendiri (modal inti) dan modal pelengkap yang karakteristiknya sama dengan modal sendiri dengan cara menjumlahkan 
10 | Prayogo. P. Harto, Umi Amaliah, Sri Mulyati : Penilaian Tingkat Kesehatan Koperasi Syariah Berdasarkan Peraturan Kementerian Koperasi dan UKM

hasil perkalian setiap komponen modalkoperasi yang ada dalam neraca dengan bobot pengakuannya;

b. Menghitung nilai ATMR diperoleh dengan cara menjumlahkan hasil perkalian nilai nominal aktiva yang ada di dalam neraca dengan bobot risiko masing-masing komponen aktiva;

c. Rasio CAR dihitung dengan cara membandingkan nilai modal yang diakui dengan nilai ATMR dikalikan dengan $100 \%$ maka diperoleh rasio CAR;

d. Untuk rasio CAR lebih kecil dari $6 \%$ diberi nilai kredit 25, untuk kenaikan rasio CAR $1 \%$ nilai kredit ditambah dengan 25 sampai dengan nilai CAR $8 \%$ nilai kredit maksimal 100 ;

e. Nilai kredit dikalikan dengan bobot $5 \%$, diperoleh skor CAR.

Tabel 6. Penetapan Kriteria Rasio Kecukupan Modal

\begin{tabular}{|c|c|c|c|c|}
\hline Rasio CAR (\%) & Nilai Kredit & Bobot $(\boldsymbol{\%})$ & Skor & Kriteria \\
\hline$<6$ & 25 & 5 & 1,25 & Tidak Sehat \\
\hline $6-<7$ & 50 & 5 & 2,50 & Kurang Sehat \\
\hline $7-<8$ & 75 & 5 & 3,75 & Cukup Sehat \\
\hline$>8$ & 100 & 5 & 5,00 & Sehat \\
\hline
\end{tabular}

Tabel 7. Perhitungan Rasio Kecukupan Modal

\begin{tabular}{|c|c|c|c|c|c|c|}
\hline $\begin{array}{c}\text { Modal } \\
\text { Tertimbang (A) }\end{array}$ & ATMR (B) & $\begin{array}{c}\text { (A/ B) X } \\
\mathbf{1 0 0 \%}\end{array}$ & $\begin{array}{c}\text { Nilai } \\
\text { kredit }\end{array}$ & $\begin{array}{c}\text { Bobot } \\
\text { \% }\end{array}$ & Skor & Kriteria \\
\hline $1.301 .892 .611,73$ & $3.576 .057 .747,50$ & $36 \%$ & 100 & $5 \%$ & 5 & Sehat \\
\hline
\end{tabular}

Dari perhitungan diperolehan nilai rasio CAR Koperasi X adalah $36 \%$ dengan skor 5, yang dapat dikategorikan Sehat. Dari skor tersebut dapat diartikan Koperasi Syariah X memiliki modal yang cukup untuk mengantisipasi risiko kerugian di masa depan.

\subsection{TINGKAT KESEHATAN KUALITAS AKTIVA PRODUKTIF}

Penilaian terhadap kualitas aktiva produktif didasarkan pada 3 (tiga) rasio, yaitu: (a) Rasio tingkat piutang dan pembiayaan bermasalah terhadap jumlah piutang dan pembiayaan; (b) Rasio portofolio terhadap piutang berisiko dan pembiayaan berisiko PAR (Portofolio Asset Risk); (c) Rasio Penyisihan Penghapusan Aktiva Produktif (PPAP) terhadap Penyisihan Penghapusan Aktiva Produktif Yang Wajib Dibentuk (PPAPWD).

\subsubsection{Rasio Pembiayaan dan Piutang Bermasalah}

Untuk memperoleh skor dan kriteria rasio pembiayaan dan piutang bermasalah terhadap jumlah piutang dan pembiayaan, ditetapkan dengan tahap sebagai berikut:

a. Untuk rasio lebih besar dari $12 \%$ sampai dengan $100 \%$ diberi nilai skor 25 ;

b. Untuk setiap penurunan rasio $3 \%$ nilai kredit ditambah dengan 25 sampai dengan maksimum 100;

c. Nilai kredit dikalikan bobot $10 \%$ diperoleh skor penilaian. 
Jurnal Ekonomi dan Perbankan Syariah

Vol. 7. No.2, Agustus 2018: 5-26, ISSN (cet): 2355-1755 | ISSN (online): 2579-

6437

| 11

Tabel 8. Penetapan Kriteria Rasio Pembiayaan dan Piutang Bermasalah

\begin{tabular}{|c|c|c|c|c|c|}
\hline Rasio (\%) & $\begin{array}{c}\text { Nilai } \\
\text { Kredit }\end{array}$ & Bobot $(\%)$ & Skor & \multicolumn{2}{|c|}{ Kriteria } \\
\hline$>12$ & 25 & 10 & 2,25 & $0-<2,50$ & Tidak Lancar \\
\hline $9-12$ & 50 & 10 & 5,00 & $2,50-<5,00$ & Kurang Lancar \\
\hline $5-8$ & 75 & 10 & 7,50 & $5,00-<7,50$ & Cukup Lancar \\
\hline$<5$ & 100 & 10 & 10,00 & $7,50-10,00$ & Lancar \\
\hline
\end{tabular}

Tabel 9. Perhitungan Rasio Tingkat Pembiayaan Bermasalah

\begin{tabular}{|c|c|c|r|r|r|c|}
\hline $\begin{array}{c}\text { Pembiayaan \& } \\
\text { Piutang } \\
\text { Bermasalah }\end{array}$ & $\begin{array}{c}\text { Pembiayaan dan } \\
\text { Piutang }\end{array}$ & $\begin{array}{c}\mathbf{( A / B ) ~ X} \\
\mathbf{1 0 0 \%}\end{array}$ & $\begin{array}{c}\text { Nilai } \\
\text { Kredit }\end{array}$ & $\begin{array}{c}\text { Bobot } \\
(\%)\end{array}$ & Skor & Kriteria \\
\hline $332.288 .834,00$ & $2.643 .287 .459,00$ & $12.57 \%$ & 25 & $10 \%$ & 2,50 & $\begin{array}{c}\text { Tidak } \\
\text { Lancar }\end{array}$ \\
\hline
\end{tabular}

Pada tabel di atas rasio pembiayaan dan piutang bermasalah terhadap piutang dan pembiayaan Koperasi Syariah X mendapat dengan skor 2,50 dengan bobot skor 10 persen sehingga dikategorikan tidak lancar.

\subsubsection{Rasio Portofolio Pembiayaan Berisiko}

Untuk memperoleh skor dan kriteria rasio portofolio piutang pembiayaan berisiko, ditetapkan dengan tahap sebagai berikut:

a. Untuk rasio lebih besar dari $30 \%$ sampai dengan $100 \%$ diberi nilai kredit 25 ;

b. Untuk setiap penurunan rasio $1 \%$ nilai kredit ditambah dengan 5 sampai dengan maksimum 100;

c. Nilai kredit dikalikan bobot $5 \%$ diperoleh skor penilaian.

Tabel 10. Penetapan Kriteria Rasio Portofolio Pembiayaan Berisiko

\begin{tabular}{|c|c|c|c|c|c|}
\hline Rasio (\%) & Nilai Kredit & Bobot (\%) & Skor & \multicolumn{2}{|c|}{ Kriteria } \\
\hline$>30$ & 25 & 5 & 1,25 & $0-<1,25$ & Sangat Berisiko \\
\hline $26-30$ & 50 & 5 & 2,50 & $1,25-<2,50$ & Kurang Berisiko \\
\hline $21-25$ & 75 & 5 & 3,75 & $2,50-<3,75$ & Cukup Berisiko \\
\hline$<21$ & 100 & 5 & 5,00 & $3,75-5,0$ & Tidak Berisiko \\
\hline
\end{tabular}


12 | Prayogo. P. Harto, Umi Amaliah, Sri Mulyati : Penilaian Tingkat Kesehatan Koperasi

Syariah Berdasarkan Peraturan Kementerian Koperasi dan UKM

Tabel 11. Perhitungan Rasio Portofolio Pembiayaan Berisiko

\begin{tabular}{|c|c|c|c|c|c|c|}
\hline $\begin{array}{c}\text { Portofolio } \\
\text { Pembiayaan } \\
\text { Berisiko }\end{array}$ & $\begin{array}{c}\text { Pembiayaan } \\
\text { Disalurkan }\end{array}$ & $\begin{array}{c}\mathbf{( A / B}) \\
\mathbf{X} \\
\mathbf{1 0 0 \%}\end{array}$ & $\begin{array}{c}\text { Nilai } \\
\text { Kredit }\end{array}$ & $\begin{array}{c}\text { Bobot } \\
(\%)\end{array}$ & Skor & Kriteria \\
\hline $233.923 .630,68$ & $2.590 .311 .230,00$ & $9 \%$ & 100 & $5 \%$ & 5 & $\begin{array}{c}\text { Tidak } \\
\text { Berisiko }\end{array}$ \\
\hline
\end{tabular}

Rasio ini berfungsi untuk mengukur kemungkinan risiko macetnya pengembalian pembiayaan dari piutang dan pembiayaan yang disalurkan di periode yang sama. Dari perhitungan diperoleh rasio portofolio piutang dan pembiayaan berisiko sebesar $9 \%$, yang berarti berkategori tidak berisiko.

\subsubsection{Rasio Penyisihan Penghapusan Aktiva Produktif}

Untuk memperoleh skor dan kriteria rasio penyisihan penghapusan aktiva produktif (PPAP), ditetapkan dengan tahap sebagai berikut:

a. Mengklasifikasikan aktiva produktif berdasarkan kolektabilitas, yaitu: lancar, kurang lancar, diragukan dan macet;

b. Menghitung nilai PPAP dari neraca pada komponen cadangan penghapusan pembiayaan;

c. Menghitung PPAPWD dengan cara mengalikan komponen persentase pembentukan PPAPWD dengan kolektabilitas aktiva produktif;

1) $0,5 \%$ dari aktiva produktif lancar;

2) $10 \%$ dari aktiva produktif kurang lancar dikurangi nilai agunannya;

3) $50 \%$ dari aktiva produktif diragukan dikurangi nilai agunannya;

4) $100 \%$ dari aktiva produktif macet dikurangi nilai agunannya. Apabila nilai jaminan tidak dapat ditaksir/ diketahui maka nilai agunan sebagai pengurang adalah sebesar $50 \%$ dari baki debet.

d. Rasio penyisihan penghapusan aktiva produktif dapat dihitung dengan membandingkan nilai PPAP dengan PPAPWD dikalikan 100\%;

e. Untuk rasio PPAP sebesar $0 \%$ nilai kredit sama dengan 0 . Untuk setiap kenaikan rasio PPAP $1 \%$ nilai kredit ditambah 1 sampai dengan maksimum 100 ;

f. Nilai kredit dikalikan dengan bobot 5\%, diperoleh skor tingkat rasio PPAP.

Tabel 12. Penetapan Kriteria Rasio Penyisihan Penghapusan Aktiva Produktif

\begin{tabular}{|c|c|c|c|c|}
\hline $\begin{array}{c}\text { Rasio } \\
\text { PPAP } \\
(\%)\end{array}$ & $\begin{array}{c}\text { Nilai } \\
\text { Kredit }\end{array}$ & $\begin{array}{c}\text { Bobot } \\
(\%)\end{array}$ & Skor & Kriteria \\
\hline 0 & 0 & 5 & 0 & \multirow{4}{*}{$\begin{array}{c}0-<1,25 \text { Macet } \\
1,25-<2,5 \text { Diragukan } \\
2,5-<3,25 \text { Kurang } \\
\text { Lancar } \\
3,75-5 \text { Lancar }\end{array}$} \\
\hline 10 & 10 & 5 & 0,5 & \\
\hline 20 & 20 & 5 & 1 & \\
\hline 30 & 30 & 5 & 1,5 & \\
\hline
\end{tabular}


Jurnal Ekonomi dan Perbankan Syariah

Vol. 7. No.2, Agustus 2018: 5-26, ISSN (cet): 2355-1755 | ISSN (online): 2579-

6437

| 13

\begin{tabular}{|c|c|c|c|}
\hline 40 & 40 & 5 & 2 \\
\hline 50 & 50 & 5 & 2,5 \\
\hline 60 & 60 & 5 & 3 \\
\hline 70 & 70 & 5 & 3,5 \\
\hline 80 & 80 & 5 & 4 \\
\hline 90 & 90 & 5 & 4,5 \\
\hline 100 & 100 & 5 & 5 \\
\hline
\end{tabular}

Tabel 13. Perhitungan Rasio Penyisihan Penghapusan Aktiva Produktif

\begin{tabular}{|c|c|c|c|c|c|c|}
\hline PPAP (A) & PPAPWD (B) & $\begin{array}{c}(\mathbf{A} / \mathbf{B}) \mathbf{X} \\
\mathbf{1 0 0 \%}\end{array}$ & $\begin{array}{c}\text { Nilai } \\
\text { Kredit }\end{array}$ & $\begin{array}{c}\text { Bobot } \\
(\boldsymbol{\%})\end{array}$ & Skor & Kriteria \\
\hline $119.931 .983,67$ & $241.530 .360,76$ & $49,66 \%$ & 49.66 & $5 \%$ & 2,5 & $\begin{array}{c}\text { Kurang } \\
\text { Lancar }\end{array}$ \\
\hline
\end{tabular}

Pada perhitungan rasio penyisihan penghapusan aktiva produktif dapat dikatakan lancar apabila nilai rasio minimal 80\%. Dari perhitungan diketahui bahwa rasio penyisihan penghapusan aktiva produktif Koperasi Syariah X ada di angka 49,66\% atau kategori kurang lancar.

\subsection{TINGKAT KESEHATAN MANAJEMEN}

Perhitungan aspek manajemen diperoleh dari hasil jawaban atas wawancara. Berikut komponen dan tahap penetapan skor rasio aspek manajemen:

a. Manajemen umum 12 pertanyaan (bobot 3 atau 0, 25 nilai kredit untuk setiap jawaban pertanyaan positif).

Tabel 14. Penetapan Kriteria Manajemen Umum

\begin{tabular}{|c|c|c|}
\hline Positif & $\begin{array}{c}\text { Nilai Kredit } \\
\text { Bobot }\end{array}$ & Kriteria \\
\hline 1 & 0,25 & $\begin{array}{c}0-0,75 \text { Tidak Baik } \\
0,76-1,50 \text { Kurang } \\
\text { Baik }\end{array}$ \\
\cline { 1 - 2 } 2 & 0,50 & $\begin{array}{c}1,51-2,25 \text { Cukup Baik } \\
2,26-3,00 \text { Baik }\end{array}$ \\
\hline 3 & 0,75 & \\
\hline 4 & 1,00 & \\
\hline 5 & 1,25 & \\
\hline 6 & 1,50 \\
\hline 7 & 1,75 \\
\hline
\end{tabular}


14 | Prayogo. P. Harto, Umi Amaliah, Sri Mulyati : Penilaian Tingkat Kesehatan Koperasi Syariah Berdasarkan Peraturan Kementerian Koperasi dan UKM

\begin{tabular}{|c|c|}
8 & 2,00 \\
\hline 9 & 2,25 \\
\hline 10 & 2,50 \\
\hline 11 & 2,75 \\
\hline 12 & 3,00 \\
\hline
\end{tabular}

b. Kelembagaan 6 pertanyaan (bobot 3 atau 0, 5 nilai kredit untuk setiap jawaban pertanyaan positif)

Tabel 15. Penetapan Kriteria Kelembagaan

\begin{tabular}{|c|c|c|}
\hline Positif & $\begin{array}{c}\text { Nilai Kredit } \\
\text { Bobot }\end{array}$ & Kriteria \\
\hline 1 & 0,50 & $0-0,75$ Tidak Baik \\
\cline { 1 - 2 } 2 & 1,00 & $0,76-1,50$ Kurang Baik \\
& $1,51-2,25$ Cukup Baik \\
23 & 1,50 & $26-3,00$ Baik \\
\hline 4 & 2,00 & \\
\hline 5 & 2,50 & \\
\hline 6 & 3,00 & \\
\hline
\end{tabular}

c. Manajemen permodalan 5 pertanyaan (bobot 3 atau 0,6 niali kredit untk setiap jawaban pertanyaan positif)

Tabel 16. Penetapan Kriteria Permodalan

\begin{tabular}{|c|c|c|}
\hline Positif & $\begin{array}{c}\text { Nilai Kredit } \\
\text { Bobot }\end{array}$ & Kriteria \\
\hline 1 & 0,60 & $0-0,75$ Tidak Baik \\
\cline { 1 - 2 } 2 & 1,20 & $\begin{array}{c}0,76-1,50 \text { Kurang } \\
\text { Baik }\end{array}$ \\
\cline { 1 - 2 } $\begin{array}{c}1,51-2,25 \text { Cukup Baik } \\
2,26-3,00 \text { Baik }\end{array}$ \\
\cline { 1 - 2 } 4 & 1,80 & \\
\hline 5 & 2,40 & \\
\hline
\end{tabular}

d. Manajemen aktiva 10 pertanyaan (bobot 3 atau 0,3 nilai kredit untuk setiap jawaban pertanyaan positif) 
Jurnal Ekonomi dan Perbankan Syariah

Vol. 7. No.2, Agustus 2018: 5-26, ISSN (cet): 2355-1755 | ISSN (online): 2579-

6437

| 15

\begin{tabular}{|c|c|c|}
\hline Positif & $\begin{array}{l}\text { Nilai Kredit } \\
\text { Bobot }\end{array}$ & Kriteria \\
\hline 1 & 0,30 & \multirow{10}{*}{$\begin{array}{c}0-0,75 \text { Tidak Baik } \\
0,76-1,50 \text { Kurang } \\
\text { Baik } \\
1,51-2,25 \text { Cukup Baik } \\
2,26-3,00 \text { Baik }\end{array}$} \\
\hline 2 & 0,60 & \\
\hline 3 & 0,90 & \\
\hline 4 & 1,20 & \\
\hline 5 & 1,50 & \\
\hline 6 & 1,80 & \\
\hline 7 & 2,10 & \\
\hline 8 & 2,40 & \\
\hline 9 & 2,70 & \\
\hline 10 & 3,00 & \\
\hline
\end{tabular}

e. Manajemen likuiditas 5 pertanyaan (bobot 3 atau 0,6 nilai kredit untuk setiap jawaban pertanyaan positif)

Tabel 18. Penetapan Kriteria Likuiditas

\begin{tabular}{|c|c|c|}
\hline Positif & Nilai Kredit Bobot & Kriteria \\
\hline 1 & 0,60 & \multirow{2}{|c|}{0,75 Tidak Baik } \\
0 & 1,20 & $0,76-1,50$ Kurang Baik \\
$1,51-2,25$ Cukup Baik \\
2 & 1,80 & $2,26-3,00$ Baik \\
\hline 3 & 2,40 & \\
\hline 4 & 3,00 & \\
\hline 5 & &
\end{tabular}

Tabel 19. Hasil Perhitungan Aspek-Aspek Manajemen

\begin{tabular}{|l|c|}
\hline \multicolumn{1}{|c|}{ Aspek Manajemen } & Keterangan \\
\hline Manajemen Umum & \\
\hline Jumlah Jawaban Positif & 12 \\
\hline Nilai Kredit Bobot & 3,00 \\
\hline Kriteria & Baik \\
\hline Manajemen Kelembagaan & \\
\hline
\end{tabular}


16 | Prayogo. P. Harto, Umi Amaliah, Sri Mulyati : Penilaian Tingkat Kesehatan Koperasi Syariah Berdasarkan Peraturan Kementerian Koperasi dan UKM

\begin{tabular}{|l|c|} 
Jumlah Jawaban Positif & 5 \\
\hline Nilai Kredit Bobot & 2,50 \\
\hline Kriteria & Baik \\
\hline Manajemen Permodalan & 3 \\
\hline Jumlah Jawaban Positif & 1,80 \\
\hline Nilai Kredit Bobot & Cukup Baik \\
\hline Kriteria & 7 \\
\hline Manajemen Aktiva & 2,10 \\
\hline Jumlah Jawaban Positif & Cukup Baik \\
\hline Nilai Kredit Bobot & \\
\hline Kriteria & 4 \\
\hline Manajemen Likuiditas & 2,40 \\
\hline Jumlah Jawaban Positif & Baik \\
\hline Nilai Kredit Bobot & \\
\hline Kriteria & \\
\hline
\end{tabular}

Pada tabel di atas dapat diketahui bahwa perhitungan aspek manajemen umum mendapat nilai positif sebanyak 12 dari 12 pertanyaan, sehingga dapat dikategorikan baik. Perhitungan aspek manajemen kelembagaan mendapat nilai positif sebanyak 5 dari 6 pertanyaan sehingga dapat dikategorikan baik. Aspek manajemen permodalan mendapat nilai positif 3 dari 5 pertanyaan sehingga dapat dikategorikan cukup baik. Selanjutnya perhitungan aspek manajemen aktiva mendapat nilai positif 7 dari 10 pertanyaan sehingga dapat dikategorikan cukup sehat. Terakhir, aspek manajemen likuiditas mendapat nilai positif 4 dari 5 pertanyaan sehingga mendapat kategori baik.

\subsection{TINGKAT KESEHATAN EFISIENSI}

Penilaian efisiensi koperasi didasarkan pada 3 (tiga) rasio yaitu: (a) Rasio biaya operasional terhadap pelayanan; (b) Rasio aktiva terhadap total aset; (c) Rasio efisiensi pelayanan.

\subsubsection{Rasio Biaya Operasional Pelayanan Terhadap Partisipasi Bruto}

Untuk memperoleh skor rasio biaya operasional pelayanan terhadap partisipasi bruto, ditetapkan dengan tahap sebagai berikut:

a. Untuk rasio lebih besar dari 100 diperoleh nilai kredit 25;

b. Untuk setiap penrunan rasio $15 \%$ nilai kredit ditambahkan dengan 25 sampai dengan maksimum nilai redit 100 ;

c. Nilai kredit dikalikan dengan bobot sebesar $4 \%$ diperoleh skor penilaian.

Tabel 20. Rumus Penetapan Kriteria Biaya Operasional Pelayanan 
Jurnal Ekonomi dan Perbankan Syariah

Vol. 7. No.2, Agustus 2018: 5-26, ISSN (cet): 2355-1755 | ISSN (online): 2579-

6437

18

\begin{tabular}{|c|c|c|c|c|}
\hline Rasio (\%) & Nilai Kredit & Bobot (\%) & Skor & Kriteria \\
\hline$>100$ & 25 & 4 & 1 & Tidak Efisien \\
\hline $86-100$ & 50 & 4 & 2 & Kurang Efisien \\
\hline $71-85$ & 75 & 4 & 3 & Cukup Efisien \\
\hline$<71$ & 100 & 4 & 4 & Efisien \\
\hline
\end{tabular}

Tabel 21. Perhitungan Rasio Biaya Operasional Pelayanan

\begin{tabular}{|c|c|c|c|c|c|c|}
\hline $\begin{array}{c}\text { Biaya } \\
\text { Operasional } \\
\text { Pelayanan (A) }\end{array}$ & $\begin{array}{c}\text { Partisipasi } \\
\text { Bruto (B) }\end{array}$ & $\begin{array}{c}\text { (A/B) } \\
\mathbf{X} \\
\mathbf{1 0 0 \%}\end{array}$ & $\begin{array}{c}\text { Nilai } \\
\text { Kredit }\end{array}$ & $\begin{array}{c}\text { Bobot } \\
(\boldsymbol{\%})\end{array}$ & Skor & Kriteria \\
\hline $842.901 .476,20$ & $1.020 .053 .098,53$ & $83 \%$ & 50 & $4 \%$ & 2 & $\begin{array}{c}\text { Kurang } \\
\text { Efisien }\end{array}$ \\
\hline
\end{tabular}

Rasio operasional dikatakan efisien apabila rasio yang dihasilkan kurang dari $71 \%$. Pada tabel di atas dapat diketahui bahwa rasio biaya operasional pelayanan terhadap partisipasi bruto $83 \%$ atau mendapat skor 2 dengan mendapat kategori kurang efisien.

\subsubsection{Rasio Aktiva Tetap terhadap Total Aset}

Untuk memperoleh skor aktiva tetap terhadap total aset, ditetapkan dengan tahap sebagai berikut:

a. Untuk rasio lebih besar dari $76 \%$ diperoleh nilai kredit 25 ;

b. Untuk setiap penurunan rasio $25 \%$ nilai kredit ditambahkan dengan 25 sampai dengan maksimum nilai kredit 100 ;

c. Nilai kredit dikalikan dengan bobot sebesar $4 \%$ diperoleh skor penilaian.

Tabel 22. Penetapan Kriteria Aktiva Tetap Terhadap Total Aset

\begin{tabular}{|c|c|c|c|c|}
\hline Rasio (\%) & Nilai Kredit & Bobot $(\%)$ & Skor & Kriteria \\
\hline $76-100$ & 25 & 4 & 1 & Tidak Baik \\
\hline $51-75$ & 50 & 4 & 2 & Kurang Baik \\
\hline $26-50$ & 75 & 4 & 3 & Cukup Baik \\
\hline $0-25$ & 100 & 4 & 4 & Baik \\
\hline
\end{tabular}

Tabel 23. Perhitungan Rasio Aktiva Tetap terhadap Total Aset

\begin{tabular}{|c|c|c|c|c|c|c|}
\hline $\begin{array}{c}\text { Aktiva Tetap } \\
(\mathbf{A})\end{array}$ & Total Aset (B) & $\begin{array}{c}\mathbf{( A / B )} \\
\mathbf{X} \\
\mathbf{1 0 0 \%}\end{array}$ & $\begin{array}{c}\text { Nilai } \\
\text { Kredit }\end{array}$ & $\begin{array}{c}\text { Bobot } \\
(\boldsymbol{\%})\end{array}$ & Skor & Kriteria \\
\hline $899,721,917.00$ & $5,343,484,559.70$ & $16.84 \%$ & 100 & $4 \%$ & 4 & Baik \\
\hline
\end{tabular}


Kriteria koperasi syaria dikatakan baik apabila memiliki rasio aktiva tetap kurang dari 26\%. Pada tabel di atas dapat diketahui bahwa rasio biaya aktiva tetap terhadap total asset $16,84 \%$, sehingga tingkat efisiensi aktiva tetap Koperasi Syariah X masuk kriteria baik.

\subsubsection{Rasio Efisiensi Pelayanan}

Untuk memperoleh skor rasio efisiensi pelayanan dilakukan dengan tahap berikut:

a. Untuk rasio kurang dari 50 persen diberi nilai kredit 25;

b. Untuk setiap kenaikan 25 orang nilai skor ditambah dengan 25 sampai dengan maksimum nilai kredit 100;

c. Nilai kredit dikalikan dengan bobot sebesar $2 \%$ diperoleh skor penilaian.

Tabel 24. Penetapan Kriteria Efisiensi Pelayanan

\begin{tabular}{|c|c|c|c|c|}
\hline $\begin{array}{c}\text { Rasio } \\
(\boldsymbol{\%})\end{array}$ & $\begin{array}{c}\text { Nilai } \\
\text { Kredit }\end{array}$ & $\begin{array}{c}\text { Bobot } \\
(\boldsymbol{\%})\end{array}$ & Skor & Kriteria \\
\hline$<50$ & 25 & 2 & 0,5 & Tidak Baik \\
\hline $50-74$ & 50 & 2 & 1 & Kurang Baik \\
\hline $75-99$ & 75 & 2 & 1,5 & Cukup Baik \\
\hline$>99$ & 100 & 2 & 2 & Baik \\
\hline
\end{tabular}

Tabel 25. Perhitungan Rasio Efisiensi Pelayanan

\begin{tabular}{|c|c|c|c|c|c|c|}
\hline $\begin{array}{c}\text { Biaya Gaji } \\
\text { dan Honor } \\
\text { Karyawan (A) }\end{array}$ & $\begin{array}{c}\text { Jumlah Piutang } \\
\text { dan } \\
\text { Pembiayaan (B) }\end{array}$ & $\begin{array}{c}\mathbf{( A / B )} \\
\mathbf{1 0 0 \%}\end{array}$ & $\begin{array}{c}\text { Nilai } \\
\text { Kredit }\end{array}$ & $\begin{array}{c}\text { Bobot } \\
(\%)\end{array}$ & Skor & Kriteria \\
\hline $467.513 .226,00$ & $2.643 .287 .459,00$ & $18 \%$ & 25 & $2 \%$ & 0,2 & $\begin{array}{c}\text { Tidak } \\
\text { Baik }\end{array}$ \\
\hline
\end{tabular}

Hasil perhitungan rasio efisiensi pelayanan diperoleh nilai $18 \%$ atau mendapat skor 0,5 sehingga dapat dikategorikan tidak baik, artinya Koperasi Syariah X dapat dianggap kurang efisien dalam mengoptimalkan jumlah biaya gaji dan honor karyawan dalam memberikan pelayanan.

\subsection{TINGKAT KESEHATAN LIKUIDITAS}

Rasio pertama yang digunakan dalam penilaian likuiditas adalah rasio kas. Perhitungan rasio kas diperoleh dengan cara, membandingkan kas ditambah kas di bank terhadap kewajiban lancar yang meliputi simpanan wadiah, simpanan mudharabah, dam simpanan mudharabah berjangka dikalikan 100\%. Rasio kedua yang digunakan dalam menilai aspek likuiditas yaitu rasio 
Jurnal Ekonomi dan Perbankan Syariah

Vol. 7. No.2, Agustus 2018: 5-26, ISSN (cet): 2355-1755 | ISSN (online): 2579-

6437

19

pembiayaan terhadap dana yang diterima. Rasio ini diperoleh dengan membandingkan total pembiayaan terhadap dana yang diterima dikalikan $100 \%$.

\subsubsection{Rasio Kas}

Untuk memperoleh skor rasio kas, ditetapkan dengan tahap sebagai berikut:

a. Untuk rasio kas lebih kecil dari $14 \%$ dan lebih besar dari $56 \%$ diberi nilai kredit 25, Untuk rasio antara 14\% sampai dengan $20 \%$ dan antara $46 \%$ sampai dengan $56 \%$ diberi nilai kredit 50, rasio antara $21 \%$ sampai dengan $25 \%$ dan $35 \%$ sampai dengan $45 \%$ diberi nilai kredit 75 , dan untuk rasio $26 \%$ sampai dengan $34 \%$ diberi nilai kredit 100;

b. Nilai kredit dikalikan dengan bobot $10 \%$ diperoleh skor penilaian

Tabel 26. Penetapan Kriteria Efisiensi Pelayanan

\begin{tabular}{|c|c|c|c|c|}
\hline Rasio Kas (\%) & $\begin{array}{c}\text { Nilai } \\
\text { Kredit }\end{array}$ & $\begin{array}{c}\text { Bobot } \\
(\boldsymbol{\%})\end{array}$ & Skor & Kriteria \\
\hline$<14$ dan $>56$ & 25 & 10 & 2,5 & Tidak Likuid \\
\hline $\begin{array}{c}(14-20) \text { dan }(46- \\
56)\end{array}$ & 50 & 10 & 5 & Kurang Likuid \\
\hline $\begin{array}{c}(21-25) \text { dan (35 - } \\
45)\end{array}$ & 75 & 10 & 7,5 & Cukup Likuid \\
\hline$(26-34)$ & 100 & 10 & 10 & Likuid \\
\hline
\end{tabular}

Tabel 27. Perhitungan Rasio Kas

\begin{tabular}{|c|c|c|c|c|c|c|}
\hline Kas + Bank (A) & $\begin{array}{c}\text { Kewajiban } \\
\text { Lancar (B) }\end{array}$ & $\begin{array}{c}\mathbf{( A / B )} \\
\mathbf{1 0 0 \%}\end{array}$ & $\begin{array}{c}\text { Nilai } \\
\text { Kredit }\end{array}$ & $\begin{array}{c}\text { Bobot } \\
(\boldsymbol{\%})\end{array}$ & Skor & Kriteria \\
\hline $1.663 .062 .817,37$ & $2.726 .144 .116,80$ & $61 \%$ & 25 & $10 \%$ & 2,5 & $\begin{array}{c}\text { Tidak } \\
\text { Likuid }\end{array}$ \\
\hline
\end{tabular}

Rasio ini digunakan untuk menunjukan kemampuan koperasi dalam mengelola dana kasnya dan di satu sisi harus dapat memenuhi hutang jangka pendeknya (simpanan, tabungan dan simpanan berjangka yang telah jatuh tempo), serta di sisi lain juga harus mengusahakan agar jangan terlalu besar jumlah kas yang tercatat, agar lebih produktif karena dananya harus tersalurkan. Kondisi ideal terjadi apabila rasio kasnya 26\% - 34\% dari hutang lancar. Pada tabel di atas dapat diketahui bahwa rasio kas $61 \%$ yang artinya masuk kategori tidak likuid sehingga secara teoritis dianggap belum memiliki kemampuan yang cukup dalam memenuhi hutang jangka pendeknya. 
20 | Prayogo. P. Harto, Umi Amaliah, Sri Mulyati : Penilaian Tingkat Kesehatan Koperasi Syariah Berdasarkan Peraturan Kementerian Koperasi dan UKM

\subsubsection{Rasio Pembiayaan}

Untuk memperoleh skor pembiayaan terhadap dana yang diterima, ditetapkan dengan tahap sebagai berikut:

a. Untuk rasio kas lebih kecil dari 50\% diberi nilai kredit 25, untuk setiap kenaikan rasio $25 \%$ nilai kredit ditambah dengan 25 sampai dengan maksimum 100;

b. Nilai kredit dikalikan dengan bobot $5 \%$ diperoleh skor penilaian.

Tabel 28. Penetapan Kriteria Rasio Pembiayaan

\begin{tabular}{|c|c|c|c|c|}
\hline $\begin{array}{c}\text { Rasio } \\
\text { Pembiayaan } \\
(\%)\end{array}$ & $\begin{array}{c}\text { Nilai } \\
\text { Kredit }\end{array}$ & $\begin{array}{c}\text { Bobot } \\
(\%)\end{array}$ & Skor & Kriteria \\
\hline$<50$ & 25 & 5 & 1,25 & Tidak Likuid \\
\hline $50-74$ & 50 & 5 & 2,50 & Kurang Likuid \\
\hline $75-99$ & 75 & 5 & 3,75 & Cukup Likuid \\
\hline$>99$ & 100 & 5 & 5 & Likuid \\
\hline
\end{tabular}

Tabel 29. Perhitungan Rasio Pembiayaan

\begin{tabular}{|c|c|c|c|c|c|c|}
\hline $\begin{array}{c}\text { Total } \\
\text { Pembiayaan (A) }\end{array}$ & $\begin{array}{c}\text { Dana yang } \\
\text { Diterima (B) }\end{array}$ & $\begin{array}{c}\mathbf{( A / B}) \\
\mathbf{X} \\
\mathbf{1 0 0 \%}\end{array}$ & $\begin{array}{c}\text { Nilai } \\
\text { Kredit }\end{array}$ & $\begin{array}{c}\text { Bobot } \\
(\boldsymbol{\%})\end{array}$ & Skor & Kriteria \\
\hline $2.643 .287 .459,00$ & $2.738 .477 .934,02$ & $97 \%$ & 100 & $5 \%$ & 5 & Likuid \\
\hline
\end{tabular}

Penilaian ini digunakan untuk menilai kemampuan koperasi dalam mengoptimalkan dana hutang yang diterima untuk pembiayaan produktifnya. Dari tabel di atas dapat diketahui bahwa angka rasio adalah 97\%. Atau dikategorikan likuid, artinya Koperasi Syariah X dianggap optimal dalam memanfaatkan dana hutangnya untuk pembiayaan produktif.

\subsection{TINGKAT KESEHATAN JATI DIRI KOPERASI}

Rasio pertama yang digunakan dalam menilai aspek jati diri koperasi yaitu rasio partisipasi bruto. Rasio partisipasi bruto diperoleh dengan cara, membandingkan jumlah pasrtisipasi bruto terhadap jumlah pasrtisipasi bruto ditambah transaksi non anggota dikalikan dengan 100\%. Rasio kedua yang dignaukan dalam menilai aspek jati diri koprasi yaitu rasio promosi ekonomi anggota (PEA). Perhitungan rasio promosi ekonomi anggota diperoleh dengan cara, membandingkan manfaat ekonomi pastisipasi ditambah SHU bagian anggota terhadap total simpanan pokok ditambah simpanan wajib dikalikan $100 \%$.

\subsubsection{Rasio Partisipasi Bruto}

Untuk memperoleh skor rasio partisipasi bruto, ditetapkan dengan tahap berikut: 
Jurnal Ekonomi dan Perbankan Syariah

Vol. 7. No.2, Agustus 2018: 5-26, ISSN (cet): 2355-1755 | ISSN (online): 2579-

6437

| 21

a. Untuk rasio lebih kecil dari $25 \%$ diberi nilai kredit 25;

b. Untuk setiap kenaikan rasio $25 \%$ diberi nilai kredit 25 samapai dengan rasio lebih besar dari $75 \%$ nilai kredit maksimum 100;

c. Nilai kredit dikalikan dengan bobot $5 \%$ diperoleh skor penilaian.

Tabel 30. Penetapan Kriteria Rasio Partisipasi Bruto

\begin{tabular}{|c|c|c|c|c|}
\hline Rasio (\%) & Nilai Kredit & Bobot $(\boldsymbol{\%})$ & Skor & Kriteria \\
\hline$<25$ & 25 & 5 & 1,25 & Rendah \\
\hline $25-50$ & 50 & 5 & 2,50 & Kurang \\
\hline $50-75$ & 75 & 5 & 3,75 & Cukup \\
\hline$>75$ & 100 & 5 & 5 & Tinggi \\
\hline
\end{tabular}

Tabel 31. Perhitungan Partisipasi Bruto

\begin{tabular}{|c|c|c|c|c|c|c|}
\hline $\begin{array}{c}\text { Jumlah } \\
\text { Partisipasi } \\
\text { Bruto (A) }\end{array}$ & $\begin{array}{c}\text { Jlh Partisipasi } \\
\text { Bruto + Transaksi } \\
\text { Non Anggota (B) }\end{array}$ & $\begin{array}{c}\mathbf{( A / B )} \\
\mathbf{1 0 0 \%}\end{array}$ & $\begin{array}{c}\text { Nilai } \\
\text { Kredit }\end{array}$ & $\begin{array}{c}\text { Bobot } \\
(\boldsymbol{\%})\end{array}$ & Skor & Kriteria \\
\hline $919.775 .798,53$ & $919.775 .798,53$ & $100 \%$ & 100 & $5 \%$ & 5 & Tinggi \\
\hline
\end{tabular}

Rasio ini digunakan untuk mengukur tingkat kemampuan koperasi dalam melayani anggota, semakin tinggi nilai rasio maka semakin baik. Rasio partisipasi Koperasi Syariah mendapat skor 5,00 sehingga dapat dikategorikan tinggi, artinya kemampuan koperasi tersebut dalam melayani anggota sangat baik.

\subsubsection{Rasio Promosi Ekonomi Anggota}

Untuk memperoleh skor rasio promosi ekonomi anggota, ditetapkan sebagai berikut:

a. Untuk rasio lebih kecil dari 5\% diberi nilai kredit 25;

b. Untk setiap kenaikan rasio $3 \%$ nilai kredit ditambah dengan 25 sampai dengan rasio lebih besar dari $12 \%$ nilai kredit maksimum 100;

c. Nilai kredit dikalikan dengan bobot $5 \%$ diperoleh skor penilaian.

Tabel 32. Penetapan Kriteria Rasio Promosi Ekonomi Anggota (PEA)

\begin{tabular}{|c|c|c|c|c|}
\hline $\begin{array}{c}\text { Rasio PEA } \\
(\%)\end{array}$ & Nilai Kredit & Bobot $(\boldsymbol{\%})$ & Skor & Kriteria \\
\hline$<5$ & 25 & 5 & 1,25 & Tidak Bermanfaat \\
\hline 05-Jul & 50 & 5 & 2,50 & Kurang Bermanfaat \\
\hline
\end{tabular}


22 | Prayogo. P. Harto, Umi Amaliah, Sri Mulyati : Penilaian Tingkat Kesehatan Koperasi Syariah Berdasarkan Peraturan Kementerian Koperasi dan UKM

\begin{tabular}{|c|c|c|c|c|} 
08-Des & 75 & 5 & 3,75 & Cukup Bermanfaat \\
\hline$>12$ & 100 & 5 & 5 & Bermanfaat \\
\hline
\end{tabular}

Tabel 33. Perhitungan Rasio Promosi Ekonomi Anggota (PEA)

\begin{tabular}{|c|c|c|c|c|c|c|c|}
\hline $\begin{array}{c}\text { SHU } \\
\text { bagian } \\
\text { anggota } \\
\text { (A) }\end{array}$ & $\begin{array}{c}\text { Manfaat } \\
\text { Ekonomi } \\
\text { Partisipasi } \\
(\mathbf{B})\end{array}$ & $\begin{array}{c}\text { Simpanan } \\
\text { pokok }+ \\
\text { Simpanan } \\
\text { wajib }\end{array}$ & $\begin{array}{c}(\mathbf{A}+\mathbf{B}) / \mathbf{C} \\
\mathbf{1 0 0 \%}\end{array}$ & $\begin{array}{c}\text { Nilai } \\
\text { Kredit }\end{array}$ & $\begin{array}{c}\text { Bobot } \\
(\%)\end{array}$ & Skor & Kriteria \\
\hline $\begin{array}{c}14.620 .114 \\
, 61\end{array}$ & $\begin{array}{c}13.669 .949 \\
, 70\end{array}$ & $\begin{array}{c}273.398 .994 \\
00\end{array}$ & $10,35 \%$ & 75 & $5 \%$ & 3,75 & $\begin{array}{c}\text { Cukup } \\
\text { Bermanfaat }\end{array}$ \\
\hline
\end{tabular}

Rasio promosi ekonomi anggota akan dikategorikan bermanfaat apabila memiliki nilai rasio sama dengan atau lebih dari $12 \%$. Dalam hal ini Koperasi Syariah X mendapat skor 3,75, yang artinya bahwa pelayanan yang diberikan dianggap cukup bermanfaat bagi anggota.

\section{$\begin{array}{llll}\text { 4.7 TINGKAT KESEHATAN KEMANDIRIAN DAN } & \text { TN }\end{array}$ PERTUMBUHAN}

Penilaian terhadap kemandirian dan pertumbuhan didasarkan pada 3 (tiga) rasio, yaitu (a) Rentabilitas aset; (b) Rentabilitas ekuitas; (c) Kemandirian operasional.

\subsubsection{Rasio Rentabilitas Aset}

Untuk memperoleh skor rasio rentabilitas aset, ditetapkan dengan tahap sebagai berikut:
a. Untuk rasio rentabilitas aset lebih kecil dari 5\% diberi nilai kredit 25;
b. Untuk setiap kenaikan rasio $2,5 \%$ nilai kredit ditambah 25 sampai maksimum 100;
c. Nilai kredit dikalikan dengan bobot $3 \%$ diperoleh skor penilaian.

Tabel 34. Penetapan Kriteria Rentabilitas Aset

\begin{tabular}{|c|c|c|c|c|}
\hline Rasio (\%) & Nilai Kredit & Bobot $(\boldsymbol{\%})$ & Skor & Kriteria \\
\hline$<5$ & 25 & 3 & 0,75 & Rendah \\
\hline $5<7$ & 50 & 3 & 1,50 & Kurang \\
\hline $6<10$ & 75 & 3 & 2,25 & Cukup \\
\hline$>10$ & 100 & 3 & 3,00 & Tinggi \\
\hline
\end{tabular}


Jurnal Ekonomi dan Perbankan Syariah

Vol. 7. No.2, Agustus 2018: 5-26, ISSN (cet): 2355-1755 | ISSN (online): 2579-

6437

| 23

Tabel 35. Perhitungan Rentabilitas Aset

\begin{tabular}{|c|c|c|c|c|c|c|}
\hline $\begin{array}{c}\text { SHU Sebelum } \\
\text { Nisbah, Zakat } \\
\text { dan Pajak (A) }\end{array}$ & Total Aset (B) & $\begin{array}{c}\text { (A/B) X } \\
\mathbf{1 0 0 \%}\end{array}$ & $\begin{array}{c}\text { Nilai } \\
\text { Kredit }\end{array}$ & $\begin{array}{c}\text { Bobot } \\
(\%)\end{array}$ & Skor & Kriteria \\
\hline $177.151 .622,33$ & $5.343 .484 .559,70$ & $3,32 \%$ & 25 & $3 \%$ & 0,75 & Rendah \\
\hline
\end{tabular}

Rasio rentabilitas aset digunakan untuk mengukur kemampuan manajemen dalam mengelola harta yang dimiliki untuk menghasilkan laba kotor. Rasio rentabilitas yang baik adalah pabila nilainya sama dengan atau lebih besar dari $10 \%$. Sementara, dari perhitungan, rasio rentabilitas aset yang diperoleh Koperasi Syariah X adalah 0,75 atau masuk dalam kategori rendah. Artinya, Koperasi tersebut belum optmal menggunakan asetnya untuk menghasilkan laba.

\subsubsection{Rasio Rentabilitas Ekuitas}

Untuk memperoleh skor rasio rentabilitas ekuitas, ditetapkan dengan tahap berikut:

a. Untuk rasio rentabilitas ekuitas lebih kecil dari 5\% diberi nilai kredit 25;

b. Untuk setiap kenaikan rasio $2,5 \%$ nilai kredit ditambah 25 sampai maksimum 100;

c. Nilai kredit dikalikan dengan bobot $3 \%$ diperoleh skor penilaian.

Tabel 36. Penetapan Kriteria Rentabilitas Ekuitas

\begin{tabular}{|c|c|r|r|c|}
\hline $\begin{array}{c}\text { Rasio Rentabilitas } \\
\text { Ekuitas (\%) }\end{array}$ & Nilai Kredit & Bobot (\%) & Skor & Kriteria \\
\hline$<5$ & 25 & 3 & 0,75 & Rendah \\
\hline $5-7$ & 50 & 3 & 1,50 & Kurang \\
\hline $8-10$ & 75 & 3 & 2,25 & Cukup \\
\hline$>10$ & 100 & 3 & 3,00 & Tinggi \\
\hline
\end{tabular}

Tabel 37. Perhitungan Rentabilitas Ekuitas

\begin{tabular}{|c|c|c|c|c|c|c|}
\hline $\begin{array}{c}\text { SHU Bagian } \\
\text { Anggota (A) }\end{array}$ & $\begin{array}{c}\text { Total Ekuitas } \\
(\mathbf{B})\end{array}$ & $\begin{array}{c}(\mathbf{A} / \mathbf{B}) \mathbf{X} \\
\mathbf{1 0 0 \%}\end{array}$ & $\begin{array}{c}\text { Nilai } \\
\text { Kredit }\end{array}$ & $\begin{array}{c}\text { Bobot } \\
(\boldsymbol{\%})\end{array}$ & Skor & Kriteria \\
\hline $14.620 .114,61$ & $450.167 .754,99$ & $3 \%$ & 25 & $3 \%$ & 0,75 & Rendah \\
\hline
\end{tabular}

Rasio rentabilitas ekuitas digunakan untuk mengukur kemampuan manajemen dalam menghasilkan laba bersih terhadap total ekuitas. Pada tabel di atas dapat diketahui bahwa rasio rentabiltas ekuitas Koperasi Syariah $\mathrm{X}$ mendapatkan nilai rasio 3\% atau koegori rendah. 
24 | Prayogo. P. Harto, Umi Amaliah, Sri Mulyati : Penilaian Tingkat Kesehatan Koperasi Syariah Berdasarkan Peraturan Kementerian Koperasi dan UKM

\subsubsection{Rasio Kemandirian Operasional Pelayanan}

Untuk memperoleh skor rasio kemandirian operasional pelayanan, ditetapkan dengan tahap sebagai berikut:

a. Untuk rasio kemandirian operasional lebih kecil dari $100 \%$ diberi nilai kredit 25;

b. Untuk setiap kenaikan rasio $25 \%$ nilai kredit ditambah 25 sampai dengan maksimum 100;

c. Nilai kredit dikalikan dengan bobot $4 \%$ diperoleh skor penilaian.

Tabel 38. Penetapan Kriteria Kemandirian Operasional

\begin{tabular}{|c|c|c|c|c|}
\hline $\begin{array}{c}\text { Rasio } \\
\text { Kemandirian } \\
\text { Operasional (\%) }\end{array}$ & Nilai Kredit & Bobot (\%) & Skor & Kriteria \\
\hline$<100$ & 25 & 4 & 1 & Rendah \\
\hline $100-125$ & 50 & 4 & 2 & Kurang \\
\hline $126-150$ & 75 & 4 & 3 & Cukup \\
\hline$>150$ & 100 & 4 & 4 & Tinggi \\
\hline
\end{tabular}

Tabel 39. Perhitungan Kemandirian Operasiona

\begin{tabular}{|c|c|c|c|c|c|c|}
\hline $\begin{array}{c}\text { Pendapatan } \\
\text { Usaha (A) }\end{array}$ & $\begin{array}{c}\text { Biaya } \\
\text { Operasional } \\
\text { Pelayanan (B) }\end{array}$ & $\begin{array}{c}\mathbf{( A / B ) ~ X} \\
\mathbf{1 0 0 \%}\end{array}$ & $\begin{array}{c}\text { Nilai } \\
\text { Kredit }\end{array}$ & $\begin{array}{c}\text { Bobot } \\
(\boldsymbol{\%})\end{array}$ & Skor & Kriteria \\
\hline $1.020 .053 .098,53$ & $842.901 .476,20$ & $121 \%$ & 50 & $4 \%$ & 2 & Kurang \\
\hline
\end{tabular}

Rasio kemandirian operasional pelayanan digunakan untuk mengukur tingkat kelanjutan operasional lembaga. Dari perhitungan diperoleh rasio kemandirian operasional pelayanan Koperasi Syariah X sebesar $121 \%$ atau tergolong kurang.

\subsection{TINGKAT KESEHATAN KEPATUHAN PRINSIP SYARIAH}

Perhitungan aspek kepatuhan prinsip syariah diperoleh dari hasil jawaban atas wawancara yaitu meliputi beberapa komponen. Untuk memperoleh skor rasio partisipasi ekonomi anggota, ditetapkan dengan perhitungan nilai kredit yang didasarkan pada hasil atas jawaban dari 10 pertanyaan dengan bobot $10 \%$ sehingga setiap satu jawaban positif memperoleh nilai kredit bobot 1 (satu).

Tabel 40. Penetapan Kriteria Pelaksanaan Prinsip Syariah

\begin{tabular}{|c|c|c|}
\hline Positif & Nilai Kredit Bobot & Kriteria \\
\hline 1 & 1 & $0-2,50$ Tidak Patuh \\
\hline 2 & 2 & 2, 51 - 5, 00 Kurang Patuh \\
\hline 3 & 3 & 5, $01-7,50$ Cukup Patuh \\
\hline
\end{tabular}


Jurnal Ekonomi dan Perbankan Syariah

Vol. 7. No.2, Agustus 2018: 5-26, ISSN (cet): 2355-1755 | ISSN (online): 25796437

\section{| 25}

\begin{tabular}{|c|c|}
\hline 4 & 4 \\
\hline 5 & 5 \\
\hline 6 & 6 \\
\hline 7 & 7 \\
\hline 8 & 8 \\
\hline 9 & 9 \\
\hline 10 & 10 \\
\hline
\end{tabular}

Tabel 41. Perhitungan Pelaksanaan Prinsip Syariah

\begin{tabular}{|c|c|}
\hline Keterangan & Hasil \\
\hline Nilai Positif & 7 \\
\hline Bobot & $10 \%$ \\
\hline Nilai Kredit Bobot & 7 \\
\hline Kriteria & Cukup Patuh \\
\hline
\end{tabular}

Penilaian aspek kepatuhan prinsip syariah digunakan untuk menilai sejauh mana prinsip syariah diterapkan atau dipatuhi oleh koperasi syariah dalam melaksanakan aktivitasnya sebagai lembaga keuangan mikro syariah. Perhitungan kepatuhan prinsip syariah akan dianggap patuh apabila memiliki nilai positif minimal 8. Pada tabel di atas dapat diketahui bahwa perhitungan aspek kepatuhan prinsip syariah Koperasi Syariah X mendapat nilai positif sebanyak 7 dari 10 pertanyaan yang diajukan sehingga dapat dikategorikan cukup patuh.

\section{SIMPULAN}

Tingkat kesehatan suatu koperasi syariah berdasarkan Peraturan Kementerian Koperasi dan UKM No 06/Per/Dep.6/IV/2016 dapat dibagi dalam 4 (empat) predikat, yaitu Sehat (skor 80 - 100), Cukup Sehat (66 - 79), Dalam Pengawasan (51 - 65), dan Dalam Pengawasan Khusus (0 - 50). Hasil rekapitulasi penilaian kesehatan Koperasi Syariah X dengan delapan aspek yang diukur; (1) permodalan; (2) kualitas aktiva produktif; (3) manajemen; (4) efisiensi; (5) likuiditas; (6) kemandirian dan pertumbuhan; (7) jati diri koperasi; dan (8) kepatuhan prinsip syariah, diperoleh total skor 61,99 atau masuk kategori Dalam Pengawasan. 
26 | Prayogo. P. Harto, Umi Amaliah, Sri Mulyati : Penilaian Tingkat Kesehatan Koperasi Syariah Berdasarkan Peraturan Kementerian Koperasi dan UKM

\section{DAFTAR PUSTAKA}

Buchori, N. S. (2012). Koperasi Syariah Teori dan Praktek. Banten: Pustaka Aufa Media (PAM Pres).

Eindrias, T. D., \& Azizah, D. F. (2017). Analisis Tingkat Kesehatan Koperasi Simpan Pinjam Berdasarkan Peraturan Nomor : 06 / PER / DEP . 6 / IV / 2016 ( Studi Pada Koperasi Simpan Pinjam Bahagia Kota Kediri ). Jurnal Administrasi Bisnis, 51(2), 135-140.

Hendriani, S., Ningsih, D. S., \& Fitri, K. (2015). Pengaruh Alat Perlengkapan Organisasi Koperasi (APPOK) dan Partisipasi Anggota Terhadap Keberhasilan Usaha Koperasi di Kota Pekanbaru. Jurnal Tepak Manajemen Bisnis, 7(2), 312-319.

Kementerian Koperasi, Deputi Bidang Pengawasan Kementerian Koperasi dan Usaha Kecil dan Menengah Republik Indonesia Nomor: 07/Per/Dep.6/IV/2016 tentang pedoman penilaian kesehatan Koperasi Simpan Pinjam dan Pembiayaan Syariah dan Unit Simpan Pinnjam dan Pembiayaan Syariah.

Soedarsa, H. G., \& Natalia, D. (2016). Analisis Tingkat Kesehatan Koperasi pada Koperasi Simpan Pinjam di kabupaten Tulang Bawang Barat. Jurnal Akuntansi \& Keuangan, 7(2), 169-191.

Sugiyarso, G. (2011). Akuntansi Koperasi: Sistem, Metode, dan Analisis Laporan Keuangan. Yogyakarta: PT. Buku Seru.

Sumarsono, S. (2003). Manajemen Koperasi. Yogyakarta: Graha Ilmu.

Yusuf, B. (2016). Analisis Tingkat Kesehatan Koperasi Syariah. Jurnal Bisnis Dan Manajemen, 6(1), 101-112. https://doi.org/10.15408/ess.v6i1.3124 